\title{
RB1-Inducible Coiled-Coil Protein 1
}

National Cancer Institute

\section{Source}

National Cancer Institute. RB1-Inducible Coiled-Coil Protein 1. NCI Thesaurus. Code C88178.

RB1-inducible coiled-coil protein 1 (1594 aa, $\sim 183 \mathrm{kDa}$ ) is encoded by the human RB1CC1 gene. This protein is involved in the regulation of both autophagosome formation and the cell cycle. 